\title{
Module and Learning Resources of Students for Developing a Local Wisdom-Based Biotechnology Module: a Preliminary Research
}

\author{
Desti $^{1}$, Fitmawati ${ }^{2}$, Putri Ade Rahma Yulis ${ }^{3}$, Mayta Novaliza Isda ${ }^{4}$ \\ \{email: destibio@edu.uir.ac.id\}
}

\begin{abstract}
Department of Biology Education, Faculty of Education, Universitas Islam Riau. Jl. Kaharuddin Nasution No. 113 Marpoyan 28284, Pekanbaru, Indonesia ${ }^{1}$, Department of Biology Faculty of Mathematics and Natural Sciences, Universitas Riau. Kampus Bina Widya Km 12,5 Simpang Baru Pekanbaru 28293, Indonesia ${ }^{2,4}$. Department of Chemistry Education, Faculty of Education, Universitas Islam Riau. Jl. Kaharuddin Nasution No. 113 Marpoyan 28284, Pekanbaru, Indonesia ${ }^{3}$.
\end{abstract}

\begin{abstract}
There are some of the problems faced in Biotechnology Subject. This research was aims to describe the preliminary research about the development of a local wisdombased Biotechnology module. It has been carried out with a 4-D model, which is a preliminary research. It show that students assume that the material about nibung is needed in the Biotechnology Subject. They assume that material in Biotechnology was in difficult category $(87 \%)$. Furthermore, the students rarely learning Biotechnology other than when they are in the class (74\%). Overall, students only use learning resources from internet and generally only rely on teaching materials from lecturers $(100 \%)$. Students assume that it is needed to develop the teaching materials that can help students in independent study, as well as teaching materials that discuss about local commodities. In conclusion, there is a need to develop teaching materials containing research results based on local wisdom for Biotechnology Subject.
\end{abstract}

Keywords: learning resources, biotechnology

\section{Introduction}

Nibung (Oncosperma tigillarium Jack Ridl.) is the mascot of Riau Province. That plant is identic with the symbol of Riau's Malay People. They tend to use nibung for some uses, namely: for materials of buildings, wood bridges, for traditional medicine, for fishery and used the other constructions. The inhabitants of Riau have also utilized Nibung for carpentry supplies, bridge poles, and weaponry such as swords and spears. [1]. The research about some characteristics of that plant was been conducted by characterization of morphological [2], anatomical [3], molecular of nibung [4] and the characterization of ethnobotany of nibung [5] and about local wisdom of nibung [6]. Some specific characters for describing morphology, anatomy, and molecular characters of nibung. All of those characters are needed for Biotechnology Subject to describe about the uses of nibung and can implemented in the application of nibung to increase the economic value of that plant. So, some of characters giving the informations completely.

The study discovered that the Malay people of Riau's Bengkalis Regency are particularly concerned about, respect, and support attempts to conserve nibung plants. They use the words nibung to mean wise, valuable, and wise. Riau people's local expertise in the usage of nibung 
may be seen in a variety of ways, including cultural, social economics, and eco-tourism, where there is harmony in the interaction of nature, humans, and constructed environments. It is incorporated into the local community's cultural values, rituals, and religious beliefs. It may be stated that the use of the nibung plant in Bengkalis, Riau is supported by the local population and is carried out responsibly [5].

Nibung was known as one of the members of the mangrove ecosystem by the Riau's Malay people. It can be found around their villages easily. Nibung is not used in learning in learning process in the schools or universities today yet. Our initial observation shows that the people are known about the nibung plant, but, they did not know that nibung is used as their mascot. Ironically, several Riau locals, particularly students at Universitas Islam Riau's Biology Program, are unaware of these plants. On the other hand, module is one of the media that consisting of some materials and obtaining some of the informations. It can used in Biotechnology Subject. In this case, module is one of the learning materials that important to support the students in learning process for Biotechnology.

As a result, one of the most essential elements needed to assist Biology Students' skill and understanding of their native flora is the construction of a local wisdom-based Biotechnology curriculum. In the learning process in the current Biotechnology Subject was faced by some obstacles consisting of: It was still minimal media and references as learning resources of learning process that can be used in the Biotechnology Subject. This fact is related to the problems of efforts to increase students' understanding of nibung conservation as the flora mascot of Riau ProvinceAs a result, it is important to create instructional materials that may offer students with information on contextual learning based on challenges they experience in their everyday lives. In this case, the research about development of Biotechnology module has not been conducted yet, including about local wisdom of Biotechnology module. So, it is necessary to develop a local wisdom-based Biotechnology module to increase the student knowledge about their local commodity.

This research aims to obtain information about how the results of the student's perceptions and the student learning resources of Biotechnology Subject. Those are some stages in a preliminary research of the development of the local wisdom-based Biotechnology module for Biology Student in Universitas Islam Riau. It will be used as a basis for future research to develop of module based on the research about the local commodity in Riau Province.

\section{Method}

Data was collected in the Biotechnology Subject at Universitas Islam Riau's Biology Program at Pekanbaru, Riau, Indonesia, from April to July 2020. This study used a survey approach that includes observation, interviews with Biotechnology professors, and the distribution of questionnaires to the students. The research and development process begins with the stage that will be discussed in this section. The challenges are determined at this stage by examining the student's learning materials, conducting interviews with ten students out of 92 total students, and observing student references in the Biotechnology field. Live observations of students in the Biotechnology learning process in class $6 \mathrm{~A}$ were used to gather data on student views and learning references [7].

Overall, this study conduct to get the role information about the perception of students, and their learning references in the Biotechnology Subject. The define process analysis is a stage in the process of describing the first step before conducting research and development research. 
This data is required to support the next steps. The student analysis was carried out by looking at the students' Biotechnology Subject learning experience. Percentage approaches were used to do descriptive data analysis.

Furthermore, the collection of data from the questionnaires were measured using a scoring with four answer choices for each statement, namely: 9 statements for the student's perception, and 7 questions for learning resources of the students in Biotechnology Subject. The instrument uses a Likert Scale measurement in the form of a checklist with four answer choices consisting of strongly agree, agree, disagree, and strongly disagree. Each solution has a scoring interval for each variable. The information obtained from the need analysis questionnaires was analyzed using a score system that included four answer options for each statement. It is used to define a student's impression of the Biotechnology subject, as well as their learning materials and references used in the learning process.

\section{Results and Discussions}

The findings reveal a lack of learning materials for Biotechnology Subjects that are based on research and local wisdom in the Biology Program, Education Faculty of Universitas Islam Riau, including teaching materials for students that are still not based on students' experiences, as well as the lack of contextual Biotechnology learning resources with their problems. In this scenario, instructors will need to provide learning resources that will help students reach the learning objectives that they must meet in the Biotechnology Subject. It implies that the lecturer plays a critical role in the learning process. This is consistent with the belief that instructors have a critical influence in the educational process and results [8]. It is because lecturers are required to be able to apply and integrate learning materials with the issues that students experience when it comes to Biotechnology materials. Furthermore, learning resources are all of the things that can be implemented to facilitate the learning activity for the purpose of achieving learning goals and can improve student performance in the learning process, perception, interest, and, most importantly, student attitude toward Science [9-10].

There were several challenges in the Biotechnology subject, including the lack of lecture modules created by lecturers based on their research and local expertise. Biotechnology is thought to be one of the most difficult disciplines, and students detest it. The lack of references has an influence on the learning process in this case. This is a difficulty that students in Indonesia confront [11-12].

In this case, the findings of the preliminary study are used to create research-based teaching materials. This supports the viewpoint that the outcomes of the problem analysis at the define stage are the first step in doing research and developing educational materials [7]. Researchers use the study of difficulties in that topic as a starting point for developing instructional materials and overcoming problems in the learning process.

The perceptions of the student were affected by their assumption about Biotechnology Subject. The result shows that student assume that Biotechnology consisting of easy contents to understand, especially for DNA analysis (about 87\%). It linked to the perception of student that Biotechnology Subject grouped into a not good category for them. In this case, $60 \%$ of students did not like Biotechnology Subject, especially for DNA analysis material which was not interesting for them. Furthermore, some students learns about that material when they attend the Biotechnology class only (74\%), and only doing some learning activities for finishing their assignments or their examinations (Table 1). 
Table 1. Percentages of student's perception for Biotechnology Subject

\begin{tabular}{llcc}
\hline No. & Statement Description & Average (\%) & Category \\
\hline 1 & $\begin{array}{l}\text { Perception about the presented material that given } \\
\text { by Biotechnology Lecturers is easy to understand } \\
2\end{array}$ & 78 & Agree \\
$\begin{array}{l}\text { Perception about th student's like for } \\
\text { Biotechnology Subject }\end{array}$ & 86 & Strongly Agree \\
\hline $\begin{array}{l}\text { I found that Biotechnology is useful in learning for } \\
\text { my field of study }\end{array}$ & 98 & Strongly Agree \\
5 & $\begin{array}{l}\text { I found that Biotechnology is useful in my daily life } \\
\text { Perception of DNA analysis material is easy for the } \\
\text { students }\end{array}$ & 70 & Agree \\
6 & $\begin{array}{l}\text { Perception about the student's like for DNA } \\
\text { analysis material in Biotechnology Subject }\end{array}$ & 60 & Disagree \\
7 & $\begin{array}{l}\text { Perception about how often the students study } \\
\text { about Biotechnology other than in the class }\end{array}$ & 74 & Agree \\
\hline
\end{tabular}

In terms of learning resources, students tends to get it from the lecturer or the internet. Overall, students only got the information about their learning material about Biotechnology Subject from the Biotechnology Lecturers and the internet (100\%). Students assume that it is needed to develop the teaching materials that are attractive, easy to understand, can help the students in independent study, as well as teaching materials that discuss commodities that are easily found in everyday life that make it easier for students to understand the material. According to the student, it is important to develop the module about Biotechnology, especially from research about local plants and based on the local wisdom of people in using the nibung in Riau. It will be can help the student in the learning process, and encourage their enthusiasm in learning about their mascot flora. As a result, the module provides an alternate teaching resource that may offer students with information on contextual learning based on difficulties they face in their everyday lives. This is connected to initiatives to improve pupils' knowledge of nibung conservation as Riau Province's future flora mascot.

Students are asked for their opinion about the existence of the Biotechnology course. They are fully aware that this course is useful for them in their daily life and in society. This is illustrated by the number of students who agreed with the statements in the questionnaire. Students have a positive opinion on the usefulness of Biotechnology courses in their field of study. This subject provides added value for students in their daily lives. This is reflected in the number of students who strongly agree that the Biotechnology course is beneficial for them. In implementing Biotechnology Subject lectures, students think that there is a need for adequate support and facilitation. The findings of the student need analysis questionnaire revealed that the students highly supported the construction of the Biotechnology module based on local wisdom, and that the students chose the kind of writing, how the module is built, and the learning materials to be utilized in their studies.

It is critical to do research and development in order to create a local wisdom-based Biotechnology module that can be used as a teaching tool for biology students. It was necessary to create a biotechnology curriculum that met the demands of the students. All phases of the defining analysis of Biotechnology learning content must be completed in order to create and build that learning material in this situation.

According to [11, 13-14], student needs analysis is important to be a point of view in teaching because it is through needs analysis that the lecturer, students, teaching materials, and teaching procedures can all be connected harmoniously to improve the learning process of 
students and to build the character and soft skills of students, as well as to support students in learning. This is in accordance with [9], which argues that effective and relevant learning materials are one of the most significant aspects in fostering a positive attitude toward science among Indonesian students. This subject is also suggested as a way to increase a student's knowledge.

Furthermore, it is suggested that this module can increase the student's understanding and provide solutions to their issues in that topic. According to [15], teachers in New South Wales (NSW), Australia, cited a variety of difficulties to teaching biotechnology, including the complexity of the subject matter and a lack of practical work that was appropriate for the topic of the teaching unit. A module is also a full measurement instrument and the synthesis of a software that can measure objectives [16].

This research has provided important results as a basis to develop teaching material for the Biology Students, especially for Biotechnology Subject at the university level as described by the students. Overall, students have many commented that they would like to see other learning materials for it, for example, a local wisdom based-biotechnology module. It can be an innovation for the students to help them for getting their learning gain in Biotechnology Subject. In this case, a local wisdom-based Biotechnology module seemed like a "tool" to improve their knowledge and can facilitate the integration of life-based learning in Biotechnology Subject. It can be implemented in learning in the university level to make an integration between the learning materials between the student's daily experiences. It is in line with [17] revealed that the module is of the innovation for the integration of life-based learning in the development of innovative biotechnology learning that was valid, effective, and useful at the schools, university and the local community in East Java.

\section{Conclusions}

In conclusion, the study of student views and learning resources in the Biotechnology Subject at Universitas Islam Riau reveals that students have positive reactions and expectations for the construction of a local wisdom-based Biotechnology module. They believe that a module for Biotechnology Subjects based on local wisdom is required to assist biology students in their learning process. It is feasible to build a local wisdom-based biotechnology module including study outcomes for Biology Students at Universitas Islam Riau based on preliminary investigation data.

Acknowledgments. Thanks to the Directorate of Research and Public Service, DirectorateGeneral of Research and Development for the Strengthening of the Ministry of Research, Technology and Higher Education, for funding this research through the Research and Public Service Institutes of Universitas Islam Riau (LPPM UIR) Pekanbaru.

\section{References}

[1] Desti, Fitmawati, Yulis, P.A.R., and Isda, M.N. 2018. Identification of Riau Province Maskot Flora (Oncosperma tigillarium) Jack Ridl. LPPM UIR Research Report. p: 1 - 95. [Indonesian].

[2] Desti, and Mellisa. 2017. Morphological Characterization of Mascot Flora of Riau Province (Oncosperma tigillarium) and its Development as Teaching Material for Plant Botany Subjects. Bioterdidik Journal FKIP Universitas Lampung. Vol. 5 No. 7. [Indonesian]. 
[3] Desti and Maryanti, A. 2018. Characterization of Anatomy of Nibung (Oncosperma tigillarium) and Its Development for Material Teaching. LPPM UIR Research Report. p: 1 - 115. [Indonesian].

[4] Desti, Fitmawati, Yulis, P.A.R., and Isda, M.N. 2019. Molecular Characterization of Riau Province Maskot Flora (Oncosperma tigillarium) Jack Ridl and Its Development for Material Teaching Based on Local Wisdom. LPPM UIR Research Report. p: 1 - 128. [Indonesian].

[5] Desti, Fitmawati, Yulis, P.A.R., and Isda, M.N. 2019. Characterization of Ethnobotany of Riau Province Maskot Flora (Oncosperma tigillarium) Jack Ridl. Proceeding of The Second International Conference of Science, Engineering, and Technology (ICOSET) p. 250-253.

[6] Desti, Fitmawati, Yulis, P.A.R., and Isda, M.N. 2019. Local Wisdom of Riau Province Maskot Flora (Oncosperma tigillarium) Jack Ridl in Baganbatu, Bengkalis District Riau Indonesia. Proceeding of The International Conference of CelSciTech 2019-Science, and Technology Track (ICCELT-ST 2019) p. 92-95.

[7] Thiagarajan, S. and others. 1974. Instructional Development for Training Teachers of Exceptional Children. National Center for Improvement of educational. Washington DC.

[8] Maison., Ernawati, M. D. W., Budiarti, R. S., Kurniawan, W., Ningsih, Y., Puspitasari, T. O., Jannah, N., Putra, D. S. 2019. Learning in Nature Science: Social Implication, Normality of Scientist., Attitudes Towards Investigation of Natural Science, and Interest Adds To Science Learning Time. International Journal of Scientific \& Technology Research, 8(12), 1478-1484.

[9] Astalini., Kurniawan, D. A., Kurniawan, N., Anggraini, L. 2019. Evaluation of Student's Attitude Toward Science in Indonesia. Open Journal of Educational Research (OJER), 3(1), 1-12.

[10] Asrial, Syahrial, Maison, Kurniawan, D.A,. dan Piyana, S.O. 2020. Ethnoconstructivism E-Module to Improve Perception, Interest, And Motivation of Students in Class V Elementary School. JPI, Vol. 9 No. 1.

[11] Ministry of Research, Technology and Higher Education, Directorate General of Learning and Student Affairs, Directorate of Learning. 2017. Scafolding of Teaching and Learning) Kemendikbud. Jakarta. (Indonesian).

[12] Sukasni, A., \& Efendy, H. 2017. The Problematic of Education System in Indonesia and Reform Agenda. International Journal of Education, 9(3), 183.

[13] Musika, I.K. 2018. Local Wisdom Based Character Education in Teaching Balinese to Achieve National Integration of a Nation. SHS Web of Conference, 42.00013 (2018). GC-TALE. p: 1-7.

[14] Wijana, N. 2015. Local Wisdom Oriented into Student Soft Skill Teaching Materials Department of Biology Education, Universitas Pendidikan Ganesha. Jurnal Pendidikan Indonesia, 4(2), 647-7. (Indonesian).

[15] Steele, F., and Aubusson, P. 2004. The Challenge in Teaching Biotechnology. Research in Science Education volume 34, pages365-387.

[16] Kristanto, A., Mustaji, Mariono, A., Sulistiowati, and Nuryati, D.W. 2018. Developing Media Module Proposed to Editor in Editorial Division. IOP Conf. Series: Journal of Physics: Conf. Series. 947012054.

[17] Suratno, S., Umamah, N., Narulita, E., Komaria, N. \& Khotimah, K. (2020). The Integration of LifeBased Learning Based Local Wisdom in the Development of Innovative Biotechnology Learning Models. International Association of Online Engineering. Retrieved November 26, 2020 from https://www.learntechlib.org/p/217770/. 